\title{
Density and Duration of Shade Affect Water and Nutrient Use in Greenhouse Tomato
}

\author{
Martin P.N. Gent \\ Department of Forestry and Horticulture, Connecticut Agricultural Experiment Station, P.O. Box \\ 1106, New Haven, CT 06504
}

AdDITIONAL INDEX WORDS. acclimation, irradiance, fruit production, resource use efficiency

\begin{abstract}
Shading a greenhouse may have a time-dependent effect on fruit production and water and nutrient uptake in tomato plants (Solanum lycopersicum L.) as a result of acclimation to light and a dependence on stored carbohydrate and nutrients. In 2 years in the northeastern United States, shadecloth was applied at the start of warm weather in June and the houses were shaded until late August. Simultaneous comparisons were made among greenhouse sections that were either not shaded or covered with reflective aluminized shadecloth that blocked 0.15 , $\mathbf{0 . 3 0}$, or $\mathbf{0 . 5 0}$ of direct sunlight. The amounts of water, nitrogen, and potassium taken up per day were calculated for successive 3-week intervals after shade was applied. The effect of shade on these uptake rates was compared with the effect on the rate of fruit production. There was a linear decline in water, nitrogen, and potassium uptake with increasing shade density. In each 3-week interval, water uptake under 0.5 shade density was $25 \%$ and $20 \%$ less than under no shade in 2004 and 2005, respectively. The uptake of nitrogen and potassium uptake under 0.5 shade density was $\approx 25 \%$ less than that under no shade. Shading did not affect the rate of fruit production within 3 weeks of application, but after more than 6 weeks, it was $30 \%$ less under 0.5 shade density than under no shade. The use efficiencies of radiation, water, and nutrients for fruit production increased with shade density immediately after shade were applied. These effects of shade on apparent resource use efficiencies dissipated from 3 to 6 weeks after shade was applied, because the effect of shade density on fruit production became proportionally the same as the effects on water and nutrient uptake. The water and nutrient uptake of greenhouse tomato acclimated to the change in irradiance resulting from shade within 3 weeks, but the full effect of shade on fruit production was not seen until 6 weeks after the application of shade.
\end{abstract}

Shade can be applied over a greenhouse to improve tomato quality. In hot climates, shading a tomato crop increases fruit set and yield. Studies in Egypt suggested a cloth with a 0.4 shade density was optimal; an increase to 0.5 or 0.6 shade density generally decreased plant growth and yield (El Aidy, 1986; El Gizawy et al., 1993a). In climates with more moderate temperatures, shade typically reduces yield of tomato grown in a greenhouse. The structure and covering of a greenhouse reduces light intensity, so additional shade may have no benefit. In England, a 0.23 shade density reduced yield by $20 \%$ (Cockshull et al., 1992). In Brazil, a 0.52 shade density reduced yield by $20 \%$ (Sandri et al., 2003). When shade was applied after fruit began to ripen in the northeastern United States, the effect of shade increased with duration of shading (Gent, 2007). A 0.5 shade density had no effect on total yield within 3 weeks of application compared with no shade, but yield decreased by $20 \%$ in the interval from 3 to 6 weeks after the start of shading and by $30 \%$ after more than 6 weeks of shading. Shade density had no significant effect on marketable yield, because the marketable fraction increased with shade density. In Spain, mobile shade increased marketable yield by $10 \%$ when used only on days with intense sunlight (Lorenzo et al., 2003). These studies suggest that shade is more beneficial under high compared with low sunlight intensity both on a daily and a seasonal basis. The reduction in marketable yield resulting from shade is not necessarily proportional to the reduction in light intensity.

Received for publication 10 Apr. 2008. Accepted for publication 20 May 2008. Corresponding author. E-mail: Martin.Gent@po.state.ct.us.
There is a physiological acclimation of plants to a reduced light intensity. During fruit production in greenhouses with 0.52 shade density, tomato plants had greater leaf area, although less vegetative biomass than nonshaded plants (Sandri et al., 2003). Leaf area to biomass ratio of tomato seedlings can increase severalfold under shade (De Groot et al., 2001). Water use and water use efficiency is altered by light intensity resulting from effects on leaf energy balance. Transpiration of a rose (Rosa hybrida L.) crop actually increased slightly after the greenhouse was covered with whitening with a 0.5 shade density as a result of a decrease in water stress and an increase in leaf conductance (Baille et al., 2001). However, for tomato, leaf transpiration in response to sunlight was less under shade than in a greenhouse without shade (Medrano et al., 2004). Nutrient uptake and use could be altered by shade. The recommended concentrations of nutrients to feed greenhouse tomato vary across production regions according to ambient light and temperature in those areas (Gent, 2004), suggesting the ratio of water to nutrient uptake depends on sunlight intensity. Daily variation of nutrient solution electrical conductivity (EC) in response to integrated radiation increased fruit quality but not total yield of tomato (Schwarz et al., 2001). This result suggests that the plant response to a change in light may be as short as $1 \mathrm{~d}$.

Tomato plants can mobilize carbohydrate reserves that accumulate in the stem and leaves to supply carbohydrate for fruit growth (Hocking and Steer, 1994). If tomato plants are put in darkness, the growth of fruit in later stages of development is less affected by the carbohydrate starvation than the growth of vegetative parts or fruit early in development (Baldet et al., 2002; Gary et al., 2003). Thus, the effect of shade on growth of 
established fruit could be buffered over time by current carbohydrate reserves in the plant.

Based on these observations, we hypothesize that there is an interval of days or weeks during which tomato plants acclimate to radiation in terms of changes in leaf area, biomass distribution, and fruit production. This acclimation should be observable in terms of changes over time in the radiation, water, and nutrient use efficiencies. The present work examines water and nutrient uptake of greenhouse tomato crops grown in greenhouses covered with different densities of shadecloth to determine the extent of acclimation and the characteristic time required for tomato plants in fruit production to respond fully to shade.

\section{Materials and Methods}

Growth CONDITIONs. The experiments were conducted in Hamden, CT (lat. $42^{\circ} \mathrm{N}$, long. $73^{\circ} \mathrm{W}, 50 \mathrm{~m}$ altitude) in four hoop-houses, $17.1 \mathrm{~m}$ long $\times 4.3 \mathrm{~m}$ wide $\times 2.7 \mathrm{~m}$ high, with a double glazing of $0.1-\mathrm{mm}$-thick clear polyethylene film. Plants were grown in rows or troughs of eight plants of one cultivar on four rock-wool slabs (model Talent BV; Grodan, Roermond, The Netherlands). Four cultivars of greenhouse tomato were grown in each year. Seeds of 'Buffalo' and 'Quest' from (Hydro-gardens, Colorado Springs, $\mathrm{CO}$ ) and 'Cabernet' and 'Jetstar' from (Holmes Seed Co., Canton, $\mathrm{OH}$ ) were germinated in January and seedlings were transplanted in March to a final spacing of 1.8 plants $/ \mathrm{m}^{2} 0.61-\mathrm{m}$ spacing within rows and $0.91 \mathrm{~m}$ between rows. Greenhouses were heated to a minimum temperature of 14 to $18^{\circ} \mathrm{C}$ until June. The ventilation temperature was $28^{\circ} \mathrm{C}$ in early spring falling to $24^{\circ} \mathrm{C}$ in early summer. Plants were pruned to a single stem and supported by string. Flower trusses were pruned to four or five fruit. The first fruit ripened $\approx 3$ weeks before shade was applied. Fruit began to ripen on 2 June 2004 and 23 May 2005, and fruits were harvested at 4- or 5-d intervals through August. Fruit from each subplot were combined for counting and weighing.

Treatments. Sections of greenhouses were either not shaded or were covered with reflective aluminized shadecloth (Aluminet; Polysack Industries, Tel Aviv, Israel) that blocked $0.15,0.3$, or 0.5 of direct sunlight. The 0.15 shade density was derived from the 0.3 shade density by cutting a staggered array of square $0.3 \times 0.3-\mathrm{m}$ holes in the shadecloth. The east and west halves of each greenhouse were covered with a different shade, either a combination of none and 0.5 shade density or a combination of 0.15 and 0.3 shade (Fig. 1). A 4m-wide strip of shadecloth covered the top of the houses. It was attached to a 1.8 -m-wide black woven polyethylene shadecloth rated at 0.5 shade density that covered the north and south sides of all houses, including those with no shade on top. The shade on the sides reduced the variability among rows within the greenhouse (Hamer et al., 2004).
The clear polyethylene sides were rolled up to a height of $1.5 \mathrm{~m}$ to improve ventilation when the shadecloth was applied. Shadecloth was applied on 23 June 2004 and 14 June 2005 and remained over the greenhouses for the rest of the summer. Air and leaf temperatures and photosynthetic active radiation were determined for each shade condition. Shaded thermocouples and temperature humidity transmitters (model 500; Campbell Scientific, Logan, UT) measured air temperature at a height of $1.5 \mathrm{~m}$ in the center of each greenhouse. Fine wire thermocouples (Omega Engineering, Stamford, CT) pressed against the underside of upper fully expanded leaves recorded leaf temperature. Quantum sensors (model 190; LI-COR, Lincoln, NE) measured photosynthetic active radiation $(P A R)$ within the greenhouse above the height of the crop. Readings from each sensor were taken every minute, averaged hourly, and recorded. Other sensors measured ambient sunlight and temperature in an unobstructed location outside the greenhouses.

SUPPLY OF WATER AND NUTRIENTS. A complete nutrient solution was formulated from $5 \mathrm{~N}-7.9 \mathrm{P}-31.5 \mathrm{~K}$ (Tomato formula; Hydro-gardens), calcium nitrate, and magnesium sulfate and diluted and mixed at every watering by proportioners (model A12 Advantage; Dosmatic USA, Carrollton, TX). The nutrient solution was delivered to individual plants through four-way manifolds attached to drip emitters (model PC-CNL, $8.5 \mathrm{~L} \cdot \mathrm{h}^{-1}$; Netafim, Tel Aviv, Israel). Table 1 shows the concentrations of all nutrients in the solution supplied to plants for the late 3-week interval of shade, as expected from formulation, as found by assay of the supply solution, and as found in the solution drained from the root zone. The concentrations of all nutrients were decreased gradually over time to prevent accumulation of salts in the root zone. The EC of the solution supplied to all plants was $2.2,2.0$, and $1.8 \mathrm{dS} \cdot \mathrm{m}^{-1}$ in the early, mid, and late periods of shading in each year, respectively. This corresponded to concentrations of 130,120, and $110 \mathrm{mg} \cdot \mathrm{L}^{-1}$ for nitrate- $\mathrm{N}$ and 220,200 , and $180 \mathrm{mg} \cdot \mathrm{L}^{-1}$ for potassium, respectively. The concentrations in the supply solution were not varied among shade treatments. The frequency of watering was determined by sunlight integral. Plants

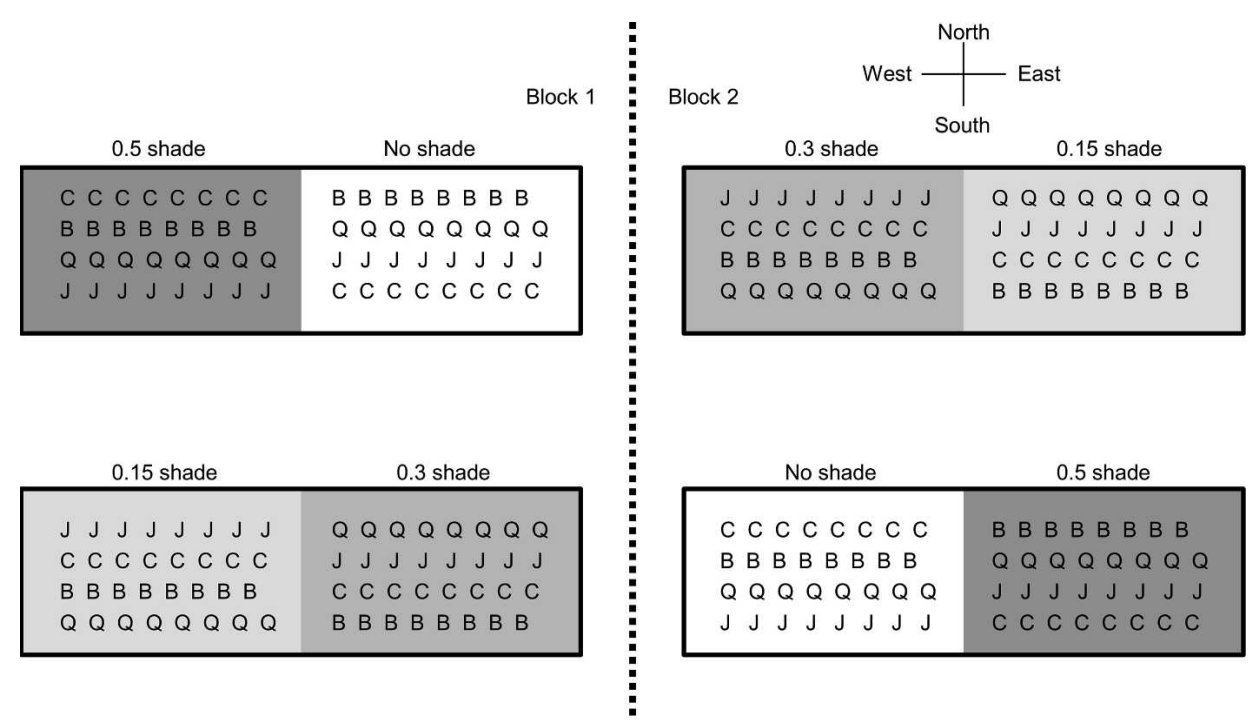

Fig. 1. Plot map of shade density treatments and cultivar subplots within four greenhouses in 2004. Shading indicates two shade density treatments within each greenhouse, and letters represent individual plants of four cultivars within each shade treatment. 
Table 1. Electrical conductivity (EC) and concentration of elements in nutrient solution supplied to greenhouse tomato plants grown in rock wool. ${ }^{\mathrm{z}}$

\begin{tabular}{|c|c|c|c|c|c|c|c|c|c|c|c|c|c|}
\hline \multirow[b]{2}{*}{ Element } & \multirow[b]{2}{*}{$\mathrm{EC}\left(\mathrm{dS} \cdot \mathrm{m}^{-1}\right)$} & \multicolumn{12}{|c|}{ Concn $\left(\mathrm{mg} \cdot \mathrm{L}^{-1}\right)$} \\
\hline & & $\mathrm{NO}_{3}-\mathrm{N}$ & $\mathrm{K}$ & $\mathrm{P}$ & $\mathrm{S}$ & $\mathrm{Ca}$ & $\mathrm{Mg}$ & $\mathrm{B}$ & $\mathrm{Fe}$ & $\mathrm{Mn}$ & $\mathrm{Zn}$ & $\mathrm{Cu}$ & Mo \\
\hline Formulation & & 113 & 189 & 107 & 42 & 132 & 32 & 1.2 & 2.40 & 1.20 & 0.30 & 0.30 & 0.06 \\
\hline Supply $2004^{y}$ & 1.8 & 115 & 175 & 86 & & 155 & 46 & & 1.55 & 1.59 & 0.31 & 0.56 & \\
\hline Root zone $2004^{x}$ & 2.5 & 79 & 131 & 30 & & 99 & 59 & & 2.60 & 0.19 & 0.19 & 1.27 & \\
\hline Root zone $2005^{x}$ & 4.1 & 287 & 362 & 64 & & 215 & 96 & & 3.03 & 0.08 & 0.30 & 2.18 & \\
\hline $\mathrm{SD}^{\mathrm{w}}$ & & 5 & 10 & 7 & & 11 & 5 & & 0.20 & 0.10 & 0.02 & 0.05 & \\
\hline
\end{tabular}

${ }^{\mathrm{z}}$ Concentrations were determined by formulation, analysis of solution supplied to the plants, and analysis of solution drained from the root zone. ${ }^{\mathrm{y}}$ Measured for solution supplied in the late 3-week interval of shade.

${ }^{\mathrm{x}}$ Averaged over drainage solution collected from all cultivars and treatments at the start of the late 3-week interval.

${ }^{\mathrm{w}}$ Variation from replicate analysis of solution supplied to the plants.

were watered at dawn and each time the sunlight integral outside the greenhouses increased by $8 \mathrm{~mol} \cdot \mathrm{m}^{-2} P A R$. The number of waterings varied from one to eight times per day. The water supply for a specific watering duration was calibrated by weighing the output of the drip emitters. The rate of supply per plant was $35 \mathrm{~mL} \cdot \mathrm{min}^{-1}$. The duration of watering was adjusted for each shade condition so the fraction drained was similar among shade treatments. In 2004, the durations were 11, 10,9 , and $9 \mathrm{~min}$, and in 2005 , the durations were $12,11,10$, and 9 min for plants grown under $0.0,0.15,0.3$, and 0.5 shade densities, respectively. The number of drippers per subplot was also altered where necessary to have a similar drain fraction among the rows in each section of each house.

Measurement OF Water AND NUTRIENT UPTAKe. The amount of water supplied to each trough or subplot of eight plants was calculated for each day based on the number of waterings, the duration of watering, the rate of flow per drip emitter, and the number of drippers per trough. The volume of water supplied per plant was determined from the supply per trough divided by the eight plants per subplot. The water drained from each trough was collected from half the subplots on 4 of $7 \mathrm{~d}$ per week. The collection containers were moved to the other half of the subplots on alternate weeks. The fraction of water drained was calculated for each day that drain volume was measured for a particular subplot and averaged over all relevant measurements for that subplot in each analysis interval. The volume of water drained per plant each day was calculated from the volume supplied times the average fraction drained, and volume taken up was the difference between the supply and drained volumes.

The EC and concentrations of nitrogen and potassium were measured in the solution from the proportioners every 2 weeks. These concentrations were constant during each 3-week analysis interval. The $\mathrm{pH}$ and EC for each sample of water drained from the subplots were measured daily (model HI 9813-0; HANNA Instruments, Woonsocket, RI). Once per week, these samples were analyzed for nitrate-nitrogen and potassium using ion selective electrodes (models 934601 and 931901; Thermo Fisher Scientific, Waltham, MA). The ratio of nitrogen and potassium to EC was determined for each sample. In 2004, these ratios varied from 20 to $60 \mathrm{mg} \cdot \mathrm{L}^{-1}$ per dS $\cdot \mathrm{m}^{-1}$ for nitrogen and from 20 to $95 \mathrm{mg} \cdot \mathrm{L}^{-1}$ per $\mathrm{dS} \cdot \mathrm{m}^{-1}$ for potassium depending on subplot and analysis interval. In 2005, these ratios varied from 40 to $75 \mathrm{mg} \cdot \mathrm{L}^{-1}$ per dS. ${ }^{-1}$ for nitrogen and from 50 to $120 \mathrm{mg} \cdot \mathrm{L}^{-1}$ per $\mathrm{dS} \cdot \mathrm{m}^{-1}$ for potassium. The average ratio for each subplot was used to interpolate the concentrations of nitrogen and potassium from EC of the drained solutions on days when these concentrations were not measured. The average of these interpolated values was the concentration used to determine the amounts in drained solutions on a daily basis. The uptake of nitrogen or potassium each day was calculated from the amounts in the solution supplied to the plants corrected for the amounts in the drained solution.

Tissue ANALysis. Samples of leaves and fruit were collected for analysis of composition 1 month after the application of shade. The fifth leaf from the apex was taken from four plants within each treatment and cultivar, combined in a bag, frozen on dry ice, and freeze-dried. Petiole and leaf blade tissues were separated and ground to a fine powder. A $250-\mathrm{mg}$ subsample was digested in $4 \mathrm{~mL}$ boiling $\mathrm{H}_{2} \mathrm{SO}_{4}$ to which $10 \mathrm{~mL}$ of $30 \mathrm{w} / \mathrm{v} \%$ $\mathrm{H}_{2} \mathrm{O}_{2}$ was added dropwise. The clear solution was diluted to $100 \mathrm{~mL}$. Total reduced N was determined using Nessler's reagent, and $\mathrm{K}, \mathrm{P}$, and minor nutrients were analyzed by inductively coupled plasma atomic absorption (Gent, 2002). A 100-mg subsample was extracted with chloroform methanol water to remove soluble metabolites. Starch in the insoluble residue was determined by colorimetric analysis with $\mathrm{K}_{3} \mathrm{Fe}(\mathrm{CN})_{6}$ (Gent, 1984) after digestion with amyloglucosidase (catalog 10115; Sigma-Aldrich, St. Louis, MO). Two fruits from each subplot were homogenized in a blender. A 10-g subsample of tissue was weighed into a weigh dish and this was dried at $70{ }^{\circ} \mathrm{C}$ and reweighed to determine dry matter content. Samples were collected for each duplicate subplot of cultivar and shade treatment. Analysis was done twice on each sample.

EXPERIMENTAL DESIGN. The experimental design was a split plot with four shade densities as treatments within the main plots. Each of four greenhouses had a different shade density in east and west sections. The four greenhouses were grouped into two blocks of two greenhouses each that included all four shade densities. Subplots consisted of one row of eight plants of one cultivar. There were four rows with different cultivars within each shaded section of each greenhouse as shown in Figure 1. There were two replications of each combination of shade treatment and cultivar in each year. The location of cultivars and shade treatments were varied between years.

AnaLYsis. The effects of shade on uptake of water and nutrients and yield were calculated within consecutive 3-week intervals after shade was applied. Each interval corresponded to five or six fruit harvests. Analysis of variance used the general linear model in Systat (version 10; Systat Software, San Jose, CA). The error term for the factors year and shade density consisted of all interaction terms of year and shade with block. 
The error to determine significance of cultivar, and all interactions of cultivar with other effects, was the residual error remaining after factoring all main effects and interactions. Shade density was a treatment factor with quantitative levels. Only the linear effects of shade density were included. Quadratic or cubic effects were never significant. The three intervals for duration of shade were treated as repeated measures within subplots. The significance of shade density on water and nutrient uptake and yield was also analyzed by linear regression within each year and 3-week interval as shown in Figs. 2 through 4. The error indicated for each symbol in these figures includes the variance between cultivars and replicate plots. Instantaneous radiation, water and nutrient use efficiencies were calculated from the rate of fruit production
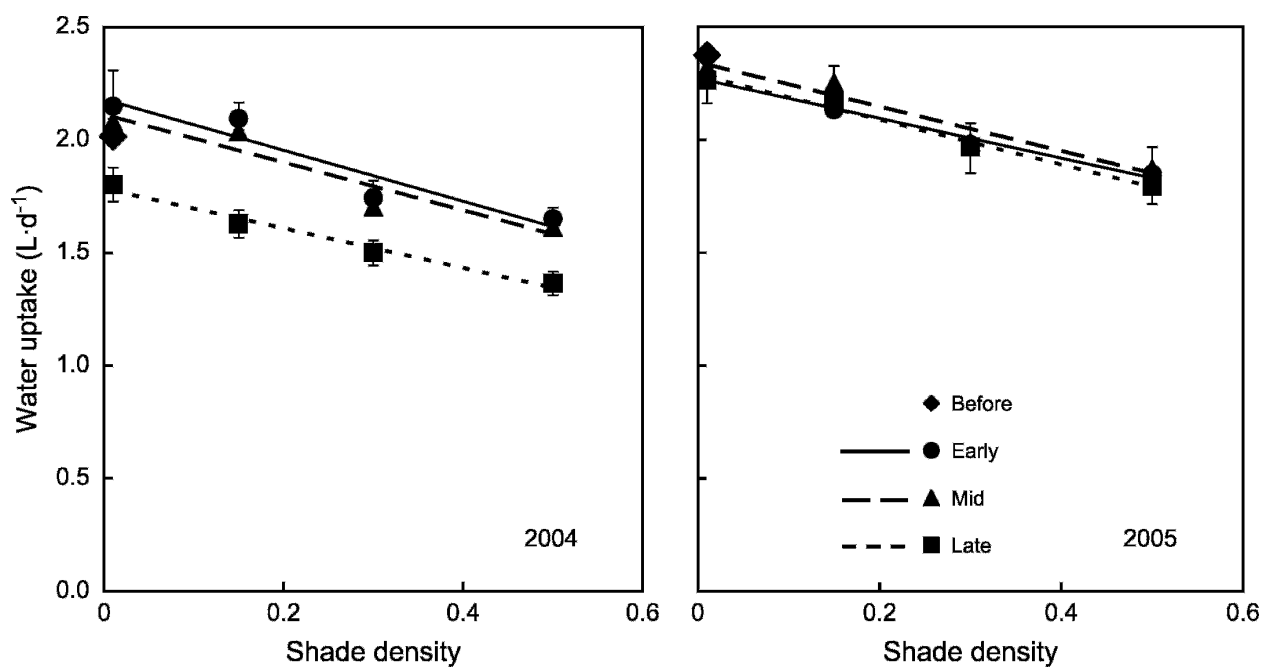

Fig. 2. Daily uptake of water by greenhouse tomato plants as a function of shade density in 2004 and 2005 . Results are separated into 3-week intervals: before application of shade, early, mid, and late intervals after application of shade. Symbols are means over four cultivars with SE indicated by error bars. Lines are linear trends versus shade density. All linear trends are significant at $P<0.001$.
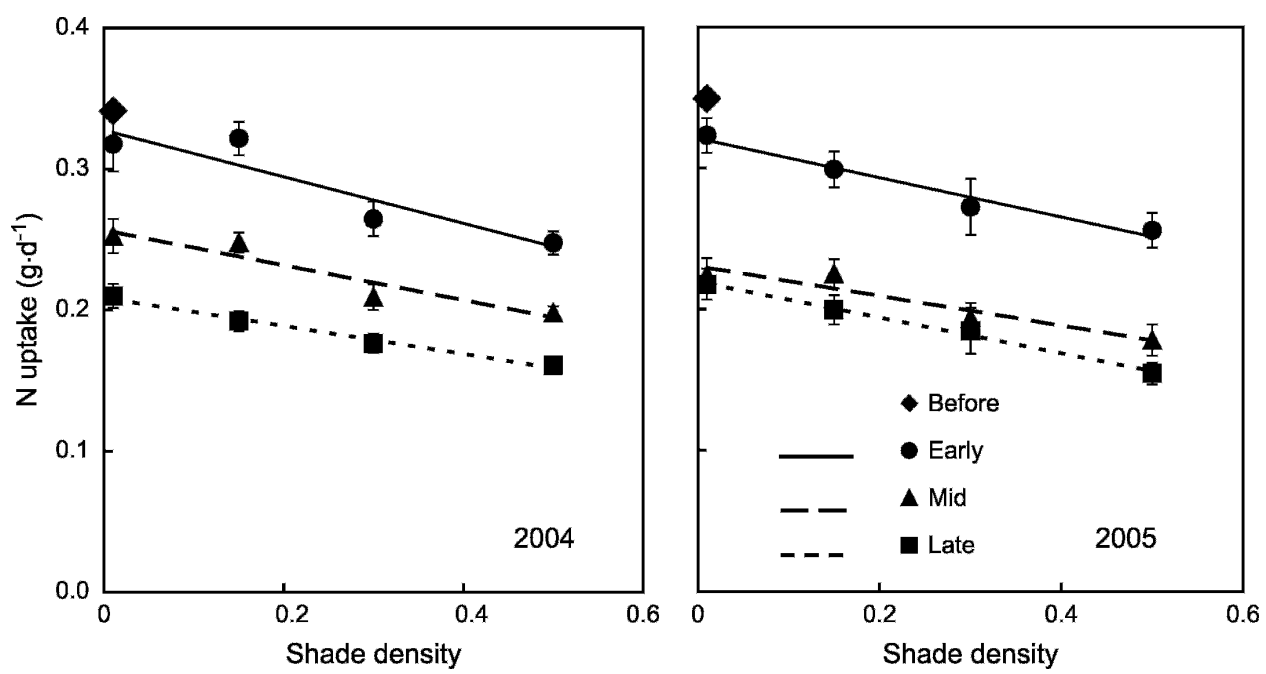

Fig. 3. Daily uptake of nitrogen by greenhouse tomato plants as a function of shade density in 2004 and 2005 . Results are separated into 3-week intervals: before application of shade, early, mid, and late intervals after application of shade. Symbols are means over four cultivars with sE indicated by error bars. Lines are linear trends versus shade density. All linear trends are significant at $P<0.001$. (dry matter basis) for each 3-week interval, divided by the integrated radiation incident on the plant, or the water, or nutrient uptake per plant, integrated over the 3-week interval.

\section{Results}

Environment. The reduction in $P A R$ under each shade treatment was very close to the nominal shade density rating (Table 2). The PAR in the nonshaded sections was $\approx 30 \%$ less than that outside the greenhouse. The average daily integrated $P A R$ outside the greenhouse was 37,30 , and $33 \mathrm{~mol} \cdot \mathrm{m}^{-2} \cdot \mathrm{d}^{-1}$ in 2004 and 41,37 , and $44 \mathrm{~mol} \cdot \mathrm{m}^{-2} \cdot \mathrm{d}^{-1}$ in 2005 in the early, mid, late 3 -week intervals after shading, respectively. Air temperature did not vary between greenhouses. The temperature in all houses was less than $1{ }^{\circ} \mathrm{C}$ warmer than ambient at night, and $\approx 2.5^{\circ} \mathrm{C}$ warmer than ambient in the day, during the period when plants were shaded. Shade density altered sunlight intensity with relatively little effect on air temperature, because the radiation balance was similar for each greenhouse. Each house included two sections that were shaded to different extents, resulting in either a $25 \%$ or $28 \%$ attenuation of sunlight averaged across both sections. The effect of shade on leaf temperature depended on sunlight intensity (Gent, 2007). Leaves that were not shaded were 1.5 to $1.8{ }^{\circ} \mathrm{C}$ warmer than those under 0.5 shade density when sunlight outside the greenhouses was greater than $1.6 \mathrm{mmol} \cdot \mathrm{m}^{-2} \cdot \mathrm{s}^{-1} P A R$.

EFFECTS ON WATER AND NUTRIENT UPTAKE. Analysis of variance of the uptake of water by tomato plants showed significant effects of year, shade density, and duration after application of shade (Table 3). All these factors, except year, also affected nitrogen and potassium uptake. Averaged over treatments and cultivars, the amount of water supplied, the fraction of water drained, and the concentration of nitrogen and potassium in the drainage solution were less in 2004 than in 2005. The water supplies per plant averaged overall periods of shading were $2.2,2.2,1.9$, and 1.8 $\mathrm{L} \cdot \mathrm{d}^{-1}$ in 2004 and 2.6, 2.4, 2.2, and $2.0 \mathrm{~L} \cdot \mathrm{d}^{-1}$ in 2005 for plants under no shade or $0.15,0.3$, and 0.5 shade densities, respectively. The average fractions of the water supplied that drained from the plants under each shade condition were $0.095,0.122$, 0.113 , and 0.117 in 2004 and 0.119 , $0.101,0.109$, and 0.121 in 2005 under no shade or $0.15,0.3$, and 

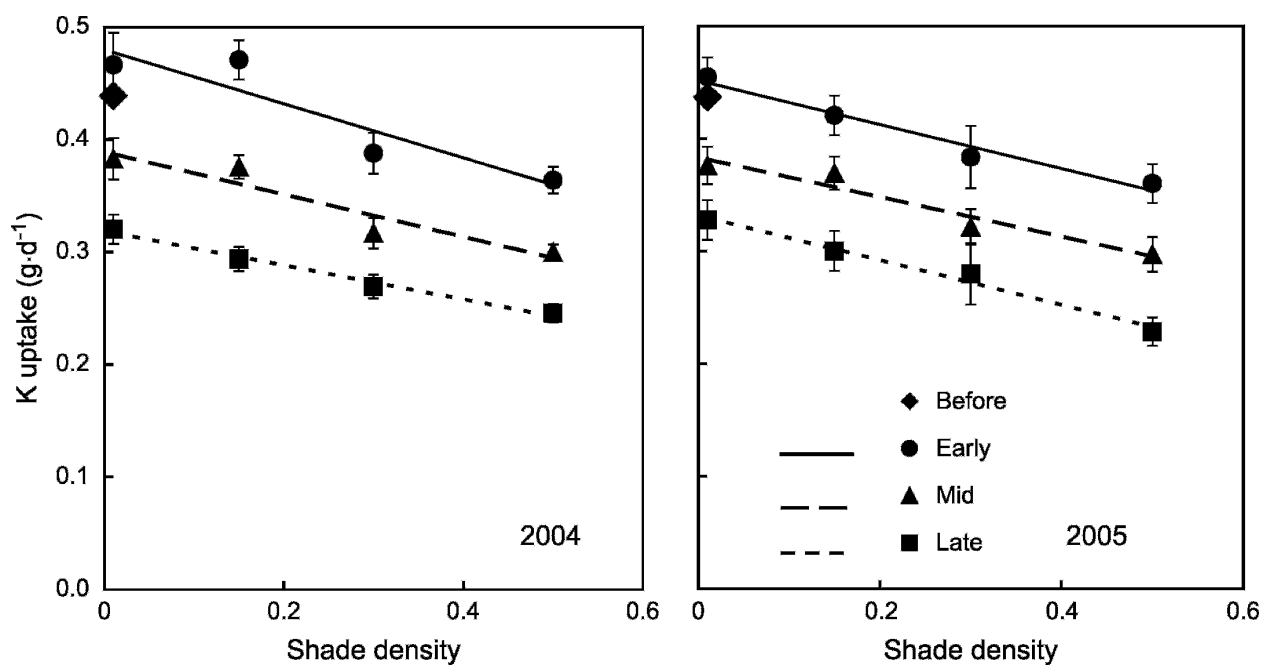

Fig. 4. Daily uptake of potassium by greenhouse tomato plants as a function of shade density in 2004 and 2005. Results are separated into 3-week intervals: before application of shade, early, mid, and late intervals after application of shade. Symbols are means over four cultivars with SE indicated by error bars. Lines are linear trends versus shade density. All linear trends are significant at $P<0.001$.

Table 2. Daily integrated photosynthetic active radiation $(P A R)$ and air temperature in greenhouses covered with a double layer polyethylene film and aluminized shadecloth ${ }^{\mathrm{z}}$.

\begin{tabular}{|c|c|c|c|c|}
\hline \multirow[b]{3}{*}{ Yr } & \multicolumn{4}{|c|}{ Daily integrated $P A R\left(\mathrm{~mol} \cdot \mathrm{m}^{-2} \cdot \mathrm{d}^{-1}\right)$} \\
\hline & \multirow{2}{*}{$\begin{array}{c}\text { Compared with outside } \\
\text { no shade }\end{array}$} & \multicolumn{3}{|c|}{ Compared with nonshaded section } \\
\hline & & 0.15 Shade & 0.30 Shade & 0.50 Shade \\
\hline 2004 & 0.763 & 0.850 & 0.690 & 0.560 \\
\hline \multirow[t]{4}{*}{2005} & 0.679 & 0.837 & 0.709 & 0.546 \\
\hline & \multicolumn{4}{|c|}{ Air temp $\left({ }^{\circ} \mathrm{C}\right)$} \\
\hline & \multicolumn{2}{|c|}{ Outside } & \multicolumn{2}{|c|}{ In greenhouse ${ }^{y}$} \\
\hline & Night & Day & Night & Day \\
\hline 2004 & 21.2 & 26.6 & 21.9 & 29.1 \\
\hline 2005 & 19.8 & 28.4 & 20.5 & 31.0 \\
\hline
\end{tabular}

${ }^{\mathrm{z}} P A R$ of a nonshaded section expressed as a fraction of that outside and $P A R$ in shaded sections expressed as a fraction of that in the nonshaded sections. All values are averaged over the period of shading.

${ }^{y}$ Averaged over shade treatments or greenhouses, which did not differ significantly in air temperature.

0.5 shade densities, respectively. The average EC of the solutions drained from the root zone were 2.3, 2.5, and 3.0 $\mathrm{dS} \cdot \mathrm{m}^{-1}$ in 2004 and $3.8,4.1$, and $3.9 \mathrm{dS} \cdot \mathrm{m}^{-1}$ in 2005 for early, mid, and late shading periods, respectively. The concentration of individual elements in the drained solution were within a factor of two of that expected from formulation (Table 1), except for high values for nitrogen and magnesium in 2005 and for copper in both years, and low values for phosphorus in 2004 and manganese in both years. The higher concentrations in 2005 than 2004 reflect the fact that uptake of nutrients was similar in the 2 years, but plants took up more water in 2005 than 2004. The concentrations in the supply solutions were not altered to account for this.

The interactions of effects of year with duration of shade were significant for all plant responses. In 2004, water uptake varied with shade and duration from 2.2 to $1.5 \mathrm{~L} \cdot \mathrm{d}^{-1}$, whereas in 2005, water uptake only varied with shade density from 2.2 to $1.8 \mathrm{~L} \cdot \mathrm{d}^{-1}$ (Fig. 2). There were also differences between years in uptake of nitrogen and potassium within each interval after shade was applied (Figs. 3 and 4). One difference between years was an inadvertent 3-d interval of water stress in late May 2004, which had an effect on growth of plants throughout the rest of the season. The lower water use in 2004 than 2005 may have been the result of the water stress experienced in late May 2004. There were interactions between effects on yield of cultivar and year, cultivar and shade duration, and duration and shade density that are described in more detail in a previous publication (Gent, 2007).

WATER UPTAKE. The rate of water uptake was at or near its maximum in the interval before shading, but after the plants had reached a steady state of fruit production (Fig. 2). Those plants grown with no shade maintained this high rate of water uptake until 6 weeks after shading in 2004 and throughout the season in 2005. Shade reduced the amount of water taken up, and the relationship between shade density and water uptake was always linear and negative $(P<0.001)$. The same relative decline in water uptake with shade density was observed in each 3-week interval after shade was applied. Water uptake under 0.5 shade density was $75 \%$ and $80 \%$ of that under no shade in 2004 and 2005, respectively.

Nitrogen uptake. The maximum rate of nitrogen uptake occurred before shade was applied, and nitrogen uptake declined during fruit production, regardless of shade condition (Fig. 3). Shade reduced uptake of nitrogen in each interval after shade was applied, and the relationship between shade density and nitrogen uptake was always linear and negative $(P<0.001)$. The relative decrease in nitrogen uptake resulting from shade was similar for each interval and each year. The uptake under 0.5 shade density was $\approx 76 \%$ of that under no shade.

Potassium UPTaKe. The maximal uptake of potassium for plants under no shade occurred in the early 3 -week interval after shade was applied to the other treatments (Fig. 4). Potassium uptake decreased later in the season in both years and under all shade densities. Shade reduced uptake of potassium in each interval, and the relationship between shade density and potassium uptake was always linear and negative $(P<0.001)$. The relative decrease in potassium uptake resulting from shade was similar for each interval and each year. The uptake under 0.5 shade density was $\approx 75 \%$ of that under no shade.

The uptake of nutrients declined with time. For those plants grown under no shade in the late 3-week interval, the uptake of nitrogen was $\approx 60 \%$ of the maximum, and the uptake of potassium was $\approx 70 \%$ of the maximum. However, the uptake of water did not decrease with time, except for the late interval in 2004. Thus, the ratio of uptake of nutrients to water 
Table 3. Mean squares from analysis of variance of effects of year, shade density, cultivar, and duration of shade on uptake of water, nitrogen, and potassium and rate of fruit production on a fresh weight basis of greenhouse tomato.

\begin{tabular}{lrlllc}
\hline & & \multicolumn{3}{c}{ Uptake per plant } & $\begin{array}{c}\text { Fruit yield } \\
\text { per plant }\end{array}$ \\
\cline { 3 - 5 } Factor & df & Water & Nitrogen & Potassium & $17472^{* * *}$ \\
Year (Y) & 1 & $1.379^{* * *}$ & 0.001 & 0.001 & $4764^{* * *}$ \\
Shade density (S) & 1 & $6.193^{* * *}$ & $0.102^{* * *}$ & $0.232^{* * *}$ & 87 \\
S $\times$ Y & 1 & 0.007 & 0.000 & 0.000 & 242 \\
Error 1 & 4 & 0.041 & 0.001 & 0.001 & 487 \\
Cultivar (C) & 3 & 0.176 & 0.003 & 0.007 & $2257^{*}$ \\
$\mathrm{C} \times \mathrm{Y}$ & 3 & 0.304 & 0.004 & 0.009 & 47 \\
$\mathrm{C} \times \mathrm{S}$ & 3 & 0.010 & 0.001 & 0.002 & 242 \\
$\mathrm{C} \times \mathrm{S} \times \mathrm{Y}$ & 3 & 0.002 & 0.001 & 0.002 & 545 \\
Error 2 & 44 & 0.115 & 0.002 & 0.004 & $32397 * * *$ \\
Duration (D) & 2 & $0.292^{* * *}$ & $0.078^{* * *}$ & $0.120^{* * *}$ & $5441^{* * *}$ \\
$\mathrm{Y} \times \mathrm{D}$ & 2 & $0.260^{* * *}$ & $0.002^{* *}$ & $0.002^{*}$ & $1893^{*}$ \\
$\mathrm{~S} \times \mathrm{D}$ & 2 & 0.004 & $0.001 *$ & 0.001 & 220 \\
$\mathrm{~S} \times \mathrm{Y} \times \mathrm{D}$ & 2 & 0.016 & 0.000 & 0.001 & $2273^{* * *}$ \\
$\mathrm{C} \times \mathrm{D}$ & 6 & 0.011 & 0.000 & 0.000 & 403 \\
$\mathrm{C} \times \mathrm{Y} \times \mathrm{D}$ & 6 & 0.016 & 0.000 & 0.001 & 554 \\
$\mathrm{C} \times \mathrm{S} \times \mathrm{D}$ & 6 & 0.012 & 0.000 & 0.000 & 181 \\
$\mathrm{C} \times \mathrm{S} \times \mathrm{Y} \times \mathrm{D}$ & 6 & 0.014 & 0.000 & 0.001 & 418 \\
Error 3 & 96 & 0.012 & 0.0003 & 0.0006 & \\
\hline
\end{tabular}

The significance of linear effects of shade density are shown. Quadratic and cubic terms were never significant.

${ }^{*},{ }^{* *},{ }^{* * *}$ Significant at $P \leq 0.05,0.01$, or 0.001 , respectively.

decreased with time. The uptake of nutrients did not appear to be influenced by the concentration in the root zone. In comparison among subplots within year and shade duration, there was an inverse relation between uptake and the concentrations of nitrogen and potassium measured in the drainage solution (data not shown). Although the EC and nutrient concentrations in the root zone were consistently higher in 2005 than in 2004 (Table 1), there was no effect of year on uptake of nitrogen or potassium (Table 3).

Fruit Production RATE. An average daily rate of fruit production per plant was determined for each 3-week interval after shade was applied. The production rate was unaffected by shade within the early interval in either year (Gent, 2007). The rate for this interval was 153 and $167 \mathrm{~g} \cdot \mathrm{d}^{-1}$, averaged over shade treatments, in 2004 and 2005, respectively. Nonshaded plants continued to produce at a similar rate, $156 \mathrm{~g} \cdot \mathrm{d}^{-1}$ in the mid 3-week interval in 2005 , whereas the rate decreased with shade to $88 \%$ of that under no shade at 0.5 shade density. Fruit production for plants grown under no shade fell in the late 3-week interval to 88 and $101 \mathrm{~g} \cdot \mathrm{d}^{-1}$ in 2004 and 2005, respectively. Fruit production for those plants grown 6 weeks or more under shade declined linearly with shade density $(P<0.001)$. The rates under 0.5 shade density were $71 \%$ and $68 \%$ of those under no shade in 2004 and 2005, respectively (Gent, 2007).

Tissue Composition. When measured 1 month after shade was applied, the composition of tomato leaf blade tissue on a dry weight basis was affected more by shade than that of petiole or fruit tissue. Starch in leaf blades of plants grown under no shade was 170 and $190 \mathrm{mg} \cdot \mathrm{g}^{-1}$ in 2004 and 2005, respectively (Fig. 5A). Starch in leaf blades decreased linearly with shade density in both years. The concentration of nutrients, other than starch, generally increased with shade as shown in Figure 5BD. However, these concentrations would have increased by $\approx 5 \%$ to $8 \%$ with increasing shade density, solely as a result of the dilution effect of starch on dry matter. Only in the case of leaf nitrogen in 2004 was the increase greater than expected as a result of the effect of starch dilution. Petiole tissue had much less starch than leaf blades and the concentration of starch and nutrients changed less in response to shade density (Fig. 5). Whereas there was a consistent increase of calcium, magnesium, and phosphorus with shade density in leaf blades, these nutrients showed little change in the petiole (only phosphorus is shown in Fig. 5D). The increase with shade density of potassium in the petiole (Fig. 5C) may indicate a higher concentration circulating in the plant. The average dry matter content of fruit from nonshaded plants was greater in 2004 than 2005,61 and $56 \mathrm{mg} \cdot \mathrm{g}^{-1}$ fresh weight, respectively. Shade had a significant effect on fruit dry matter only for 'Buffalo' and 'Quest' in 2004. Compared with no shade, 0.5 shade density lowered fruit dry matter content from 65 to $59 \mathrm{mg} \cdot \mathrm{g}^{-1}$ fresh weight for these cultivars.

RAdiation, WATER, AND NUTRIENT USE EFFICIENCIES. The density and duration of shade affected the instantaneous radiation use efficiency (RUE) of tomato fruit production. There was relatively little effect of shade density on fruit dry matter fraction, so the effect of shade on RUE was similar for fresh or dry matter production in the fruit. There was an increase in RUE with shade density for all intervals after shade was applied in 2005 as shown in Figure 6A. The effect on RUE was most dramatic in the early 3 -week interval, primarily because the rate of fruit production did not change immediately after shade was applied. The effect of shade on RUE became less as the duration of shade increased, because shade gradually decreased the rate of fruit production.

Shade also increased water use efficiency (WUE) of fruit production immediately after shade was applied (Fig. 6B). The response of WUE to shade density was less than that for RUE, because shade reduced water uptake immediately, although not in proportion to shade density. The slope of the relation of WUE to shade density was not significant for mid and late 3-week intervals after shade was applied. By this time, the reduction in fruit production resulting from shade was approximately equal to the reduction in water uptake.

When nitrogen use efficiency of fruit production was calculated in a similar manner, the response to shade density was greatest in the early 3-week interval after shade was applied (Fig. 6C). However, this response to shade was no longer significant for mid and late intervals in 2004, or the late interval in 2005 , because the relative effect of shade density on nitrogen uptake was similar to that on fruit production after this duration of shade. The response of potassium use efficiency to shade density and duration (Fig. 6D) was similar to that for nitrogen use efficiency. 

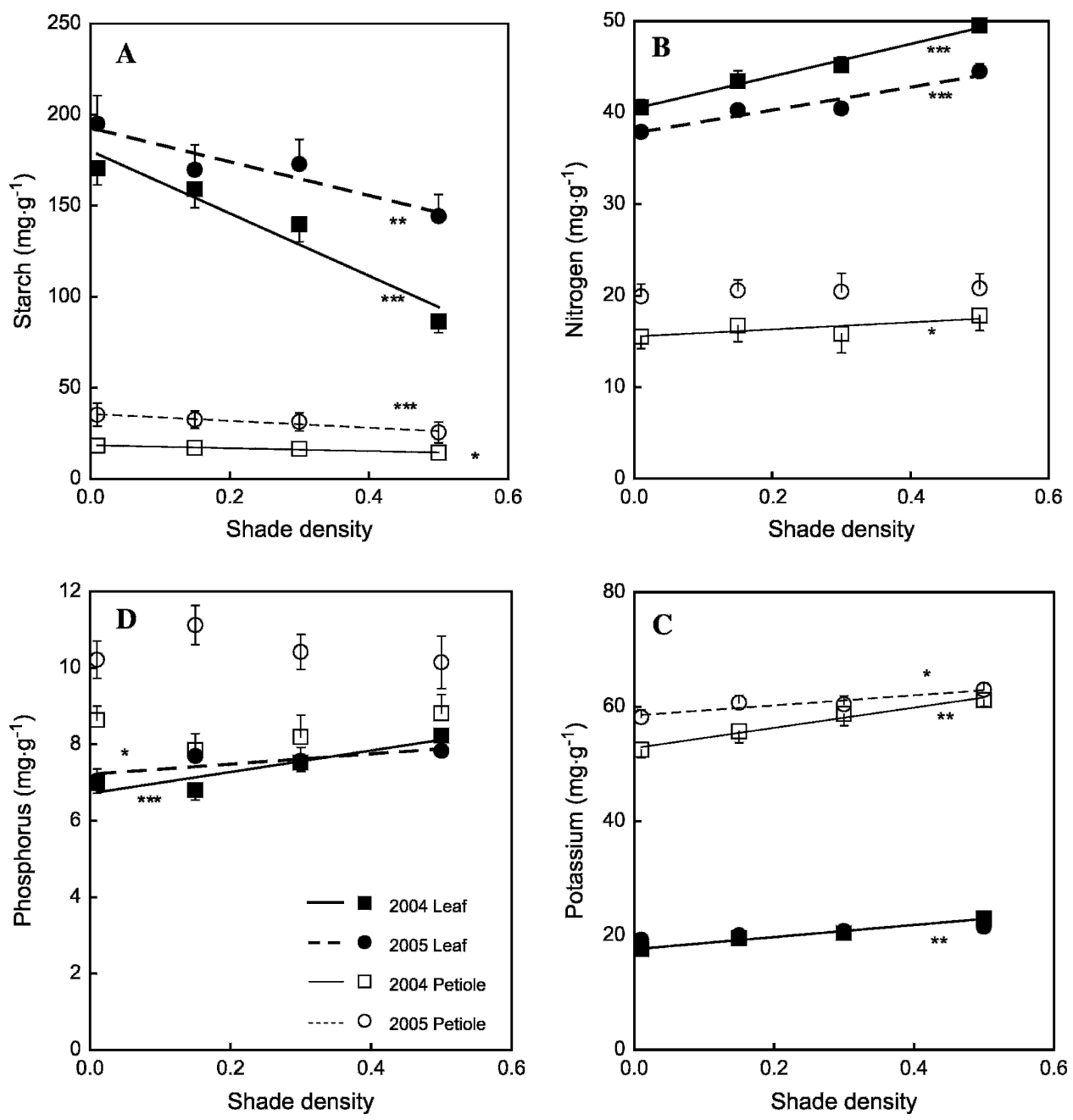

Fig. 5. Composition of leaf blades and petioles of greenhouse tomato plants on a dry weight basis as a function of shade density in 2004 and 2005. Results for (A) starch, (B) reduced nitrogen, (C) potassium, and (D) phosphorus are in separate panels. Symbols are means over four cultivars with SE indicated by error bars. Filled symbols represent leaf blades and empty symbols represent petiole tissue. Lines indicate linear trends versus shade density when significant. Significance indicated by *, **, *** for $P<0.05,0.01,0$ or 0.001 , respectively.

\section{Discussion}

There is a reduction in daytime air temperature when an entire greenhouse is shaded, and this lower temperature resulting from shade is likely a critical factor in the increase in yield of tomato grown in hot climates (El Aidy, 1986; El Gizawy et al., 1993a). The increase in yield is the result of the sensitivity of fruit set to high temperature (Sato et al., 2002). A lower temperature would lower transpiration and water uptake also. In the experimental design used here, shade density influenced incident radiation but not air temperature. Thus, the effects of shade on yield and reduction in water use may be less than would be obtained in uniformly shaded greenhouses.

There was an increase in RUE when shade was imposed after tomato plants were in their fruit production phase, because the rate of fruit production was not reduced proportional to the shade density. This effect depends on the type of shading. In Spain, moveable shade that reduced light intensity only under intense radiation, by $30 \%$ over the crop cycle, increased RUE on a fruit dry weight basis from 0.8 to $1.1 \mathrm{~g} \cdot \mathrm{mol}^{-1} P A R$ (Lorenzo et al., 2003). In Brazil, permanent anti-insect screens that lowered incident radiation increased RUE on a dry weight basis to $0.60 \mathrm{~g} \cdot \mathrm{mol}^{-1}$ compared with $0.53 \mathrm{~g} \cdot \mathrm{mol}^{-1}$ for a greenhouse without screens (Radin et al., 2003). There was also a difference in RUE resulting from shading with aluminized shading screens versus whitewash (Fernandez Rodriguez et al., 2001). In the southeastern United States, transpiration and energy gain were also not proportional to shade. The reduction in total radiation energy incident on the plants was greater with white cloth at 0.4 shade density than with black cloth at 0.5 shade density, $28 \%$ versus $15 \%$, but leaf temperature was lower with black (Willits, 2001).

In part, the increase in RUE we observed immediately after shading may be the result of the use of stored carbohydrate. Tomato seedlings grown under $1200 \mu \mathrm{L} \cdot \mathrm{L}^{-1} \mathrm{CO}_{2}$ took $2 \mathrm{~d}$ to acclimate carbon use efficiency to shade (Frantz and Bugbee, 2005). The authors speculated that in part this was the result of a reliance on stored carbohydrate. Based on computer simulations (Lattanzi et al., 2005), new leaf growth of tomato relied on shortterm carbon storage of 1 to $3 \mathrm{~d}$, whereas long-term stores supplied most of the nitrogen used in leaf growth, and shaded plants depended more on mobilization from longterm stores. Because plants in fruit production have slower growth rates and greater reserves of carbohydrate and nitrogen, they may be able to use these reserves to support fruit growth for many days.

The increase in RUE we observed may be attributable, in part, to a change in biomass distribution. When fruiting tomato plants were grown in a greenhouse under 0.52 shade density, the number of fruit did not differ but total fruit dry weight was reduced by $20 \%$, and vegetative biomass was reduced proportionally more by shade (Sandri et al., 2003). Cucumber (Cucumis sativus L.) grown in a greenhouse under 0.3 shade density produced less dry matter and had more biomass in leaves and stems and less in root and fruits than plants without shade (Smith et al., 1984). Plants acclimate to shade, in part, by increasing specific leaf area. Tomato plants grown under 0.52 shade density compared with no shade had a greater leaf area index, 4.7 and 3.9, and a greater specific leaf area, 320 and $230 \mathrm{~cm}^{2} \cdot \mathrm{g}^{-1}$, respectively (Sandri et al., 2003). We observed that the reduction in water uptake was not proportional to shade density. The water uptake or transpiration by plants under 0.5 shade density was $75 \%$ to $80 \%$ of that for plants under no shade. A proportional response to 

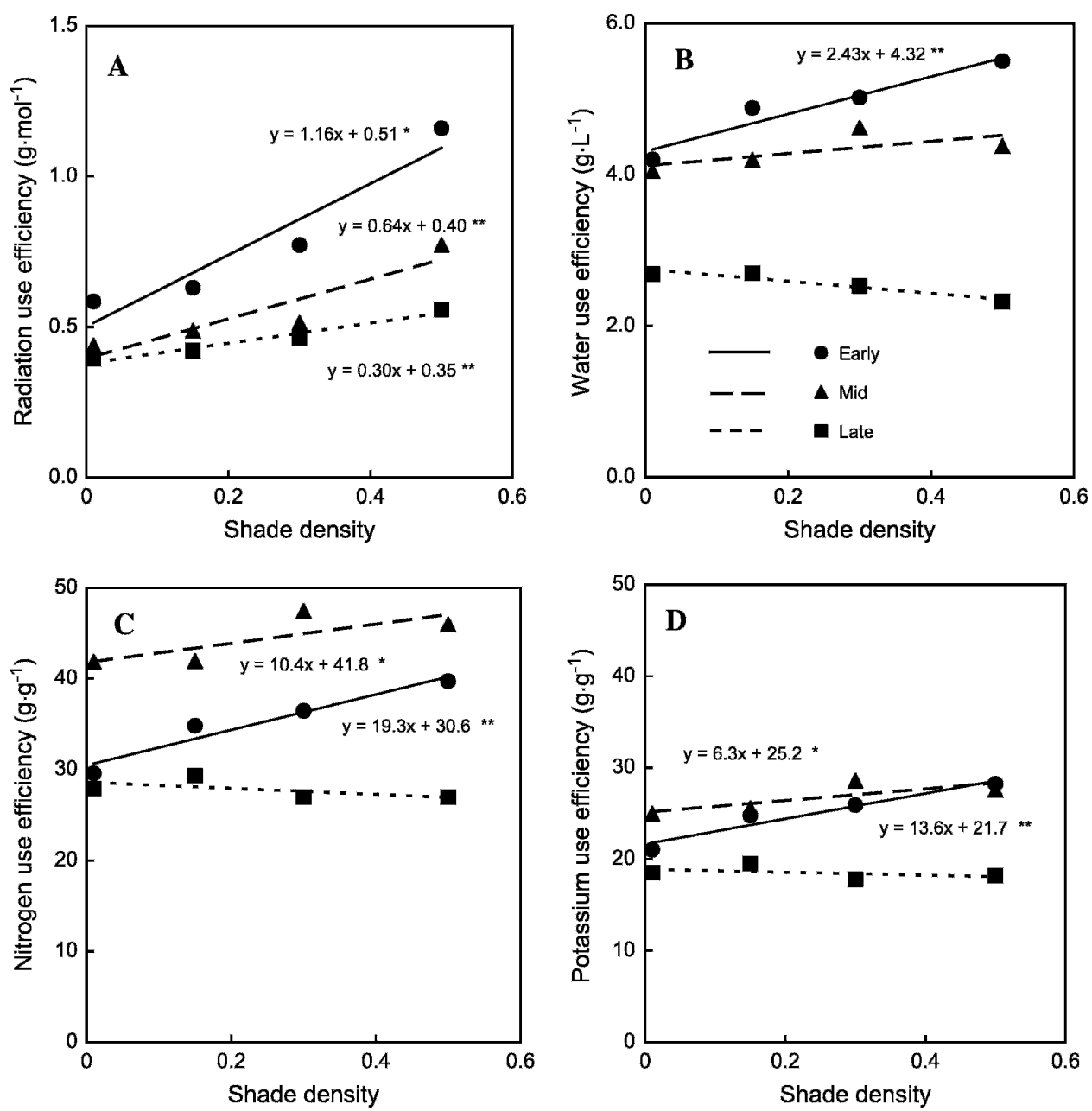

Fig. 6. Resource use efficiencies for fruit production of tomato on a dry weight basis in 2005. Results for (A) radiation, (B) water, $(\mathbf{C})$ nitrogen, and (D) potassium use efficiencies are in separate panels. Results are separated into 3-week intervals: early, mid, and late intervals after application of shade. Symbols are means over four cultivars. Lines are linear trends versus shade density. Equations are shown only for significant trends. Significance is indicated by $*$ or $* *$ at $P<0.05$ or 0.01 , respectively.

radiation would lead to a $50 \%$ decrease. Although leaf area was not measured in this experiment, the less than proportional response to shade was likely the result of a change in leaf area to biomass ratio, as observed by Sandri et al. (2003).

We observed that shade lowered starch in leaf blades and increased the concentration of other nutrients. A similar behavior was noted for field-grown plants under shade in Egypt. Shading increased nitrogen, potassium, phosphorus, and pigments in leaves, but there was less total carbohydrate (El Gizawy et al., 1993b). The use of supplemental light to increase radiation in a greenhouse had the opposite effect of decreasing potassium, but supplemental light increased calcium and magnesium (Ehret et al., 1989). We observed the concentrations of nitrogen and potassium increased in petioles, which may indicate higher concentrations of these elements mobilized in the plant. (Masuda and Shimada, 1993) reported that shade reduced the rate of exudation but increased the concentration of xylem exudate in tomato plants.

In general, the differences in tissue composition we observed after acclimation to shade appeared to be secondary effects resulting from depletion of starch rather than the much larger effect expected if nutrient uptake changed more or less than dry matter accumulation. Thus, changes resulting from shade in dry matter accumulation must have been similar to the changes in nutrient uptake. The amount of nitrogen and potassium taken up by plants under 0.5 shade density was $\approx 75 \%$ of that for plants with no shade. A proportional response to radiation would lead to a $50 \%$ decrease. Thus, after acclimation to shade, the decrease in dry matter accumulation was approximately half that expected from the change in incident radiation. Because the same response to shade density was seen in each interval after shade was applied, we can infer that acclimation of dry matter accumulation, transpiration, and nutrient uptake occurred quickly, within 3 weeks after shade was applied. The extent and time response of this acclimation was similar under each shade density; e.g., the reduction in uptake of water and nutrients occurred within 3 weeks and was approximately half the reduction in irradiance.

The response of the rate of fruit production to shade was delayed with respect to that for water or nutrient uptake. There was no response within 3 weeks after application of shade, a partial response in 3 to 6 weeks, and finally, the response was proportional to the change in uptake of water and nutrients only after 6 weeks or more. This time response may be because the rate of growth of fruit already attached to the plant is relatively resistant to changes in carbohydrate availability that are the result of changes in light level. When tomato plants were put in darkness, the growth of fruit in later stages of development was less affected by the carbohydrate starvation than the growth of vegetative parts or fruit early in development (Baldet et al., 2002; Gary et al., 2003). 'Beefsteak' tomato fruit grow on the vine for $\approx 6$ weeks from flowering to ripening. When shade was first applied, the plants had fruit at all stages of development. For fruit that ripened within 3 weeks of the start of shading, fruit set and the majority of growth occurred before shade was applied. Flowers and small fruit would have developed after 3 weeks under shade, but large fruit and ripening fruit would have been set before shade was applied. However, after 6 weeks or more, all stages of fruit development would have occurred under shade. The decline in fruit production that was seen over the long term, greater than 6 weeks, was likely the result of a decrease in flowering and fruit set in response to the change in irradiance resulting from shade. Although it was not tested in this experiment, a corollary to these observations is that a crop of tomato plants would likely 
require 6 weeks or more after shade was removed before it resumed the rate of fruit production expected without shade.

\section{Literature Cited}

Baille, A., C. Kittas, and N. Katsoulas. 2001. Influence of whitening on greenhouse microclimate and crop energy partitioning. Agr. For. Meteorol. 107:293-306.

Baldet, P., C. Devaux, C. Chevalier, R. Brouquisse, and P. Raymond. 2002. Contrasted responses to carbohydrate limitation in tomato fruit at two stages of development. Plant Cell Environ. 25:16391649.

Cockshull, K.E., C.J. Graves, and C.R.J. Cave. 1992. The influence of shading on yield of glasshouse tomatoes. J. Hort. Sci. 67:11-24.

De Groot, C.C., L.F.M. Marcelis, R. Van den Boogaard, and H. Lambers. 2001. Growth and dry-mass partitioning in tomato as affected by phosphorus nutrition and light. Plant Cell Environ. 24:1309-1317.

Ehret, D.L., P.A. Jolliffe, and J.M. Molnar. 1989. Lighting for greenhouse vegetable production: An overview. Can. J. Plant Sci. 69:1309-1326.

El Aidy, F. 1986. Tomato production under simple protective tunnels in Egypt. Acta Hort. 190:511-514.

El Gizawy, A.M., M.M.F. Abdallah, H.M. Gomaa, and S.S. Mohamed. 1993a. Effect of different shading levels on tomato plants: Yield and fruit quality. Acta Hort. 323:349-354.

El Gizawy, A.M., H.M. Gomaa, K.M. El Habbasha, and S.S. Mohamed. 1993b. Effect of different shading levels on tomato plants: Growth flowering and chemical composition. Acta Hort. 323:341-347.

Fernandez Rodriguez, E.F., D. Perez, F.C. Ferre, J.F. Vadillos, and A. Kenig. 2001. Effect of aluminized shading screens vs whitewash on tomato photochemical efficiency under a non heated greenhouse. Acta Hort. 559:279-284.

Frantz, J.M. and B. Bugbee. 2005. Acclimation of plant populations to shade: Photosynthesis respiration and carbon use efficiency. J. Amer. Soc. Hort. Sci. 130:918-927.

Gary, C., P. Baldet, N. Bertin, C. Devaux, M. Tchamitchian, and P. Raymond. 2003. Time course of tomato whole plant respiration and fruit and stem growth during prolonged darkness in relation to carbohydrate reserves. Ann. Bot. (Lond.) 91:429-438.

Gent, M.P.N. 1984. Carbohydrate level and growth of tomato plants. I. The effect of carbon dioxide enrichment and diurnally fluctuating temperatures. Plant Physiol. 76:694-699.

Gent, M.P.N. 2002. Growth and composition of salad greens as affected by organic compared to nitrate fertilizer and environment in high tunnels. J. Plant Nutr. 25:981-998.
Gent, M.P.N. 2004. Yield of greenhouse tomato in response to supplemental nitrogen and potassium. Acta Hort. 633:341-348.

Gent, M.P.N. 2007. Effect of degree and duration of shade on quality of greenhouse tomato. HortScience 42:514-520.

Hamer, P.J.C., S.R. Adams, and V.M. Valdes. 2004. Design and evaluation of a shade screen to overcome within row variability of tomato crops grown in small experimental class house compartments. Acta Hort. 633:67-73.

Hocking, P.J. and B.T. Steer. 1994. The distribution of assimilate in tomato with special reference to stem reserves. Ann. Bot. (Lond.) 73:315-325.

Lattanzi, F.A., H. Schnyder, and B. Thornton. 2005. The sources of carbon and nitrogen supplying leaf growth: Assessment of the role of stores with compartmental models. Plant Physiol. 137:383395.

Lorenzo, P., M.C.S. Guerro, E. Medrano, M.L. Garcia, I. Caparros, and M. Giminez. 2003. External greenhouse mobile shading effect on microclimate water use efficiency and the yield of a tomato crop grown under different salinity levels of the nutrient solution. Acta Hort. 609:181-186.

Masuda, M. and Y. Shimada. 1993. Diurnal changes in mineral concentration of xylem exudate in tomato plants and their concentrations as affected by sunlight intensity and plant ages. J. Jpn. Soc. Hort. Sci. 61:839-845.

Medrano, E., P. Lorenzo, M.C.S. Guerro, M.L. Garcia, I. Caparros, and M. Giminez. 2004. Influence of external greenhouse mobile shading on tomato crop transpiration. Acta Hort. 659:195-199.

Radin, B., H. Bergamaschi, C. Reisser, N.A. Barni, R. Matzenauer, and I.A. Didone. 2003. Use efficiency of photosynthetically active radiation by tomato plants grown in different environments. Pesquisa Agropecuaria Brasileira 38:1017-1023.

Sandri, M.A., J.L. Andriolo, M. Witter, and T.D. Ross. 2003. Effect of shading on tomato plants grown under greenhouse. Horticultura Brasileira 21:642-645.

Sato, S., M.M. Peet, and J.F. Thomas. 2002. Determining critical pre and post anthesis periods and physiological processes in Lycopersicon esculentum Mill exposed to moderately elevated temperatures. J. Expt. Bot. 53:1187-1195.

Schwarz, D., H.P. Klaring, K.T. Ingram, and Y.C. Hung. 2001. Model based control of nutrient solution concentration influences tomato growth and fruit quality. J. Amer. Soc. Hort. Sci. 126:778784.

Smith, I.E., M.J. Savage, and P. Mills. 1984. Shading effects on greenhouse tomatoes and cucumbers. Acta Hort. 148:491-500.

Willits, D.H. 2001. Effect of cloth characteristics on the cooling performance of external shade cloths for greenhouses. J. Agr. Eng. Res. 79:331-340. 